\title{
EDITORIAL
}

\section{Another vacation, another medical 'crisis'}

A s I've previously written in my Editorial column, vacations with the Hanauer family are typically adventuresome in one way or another. We've transited through tsunamis, eaten caterpillars and dealt with a variety of acute medical situations, including the emetogenic esophageal tear associated with subcutaneous emphysema that our middle son developed after he suffered a bout of gastroenteritis while we were in Laos several years ago (Hanauer, S. Nat. Clin. Pract. Gastroenterol. Hepatol. 2, 161; 2005).

I've also told you about our grandson, who is the love of our lives and the child of our middle son (Hanauer, S. Nat. Clin. Pract. Gastroenterol. Hepatol. 6, 63; 2009). Tyler is now 14 months old and the reason why we chose a more 'laid-back' venue for this year's family vacation. We selected Tulum, Mexico, as our destination of choice because it was easy to travel to, and we could stay in a property on an all-inclusive resort and be near to natural and man-made wonders. Yet, even a bit of the exotic can lead to unanticipated predicaments ... especially when traveling with an infant.

One day we had an aborted attempt to view sea turtles. The excursion was described as easy snorkeling in a shallow bay and we were told there was "no problem" taking along the baby who loves 'swimming' (albeit in pools, in a 'floaty' - a small swim raft with a seat). We could put Tyler in his floaty as my wife and I, his parents and our youngest son waded or swam alongside him to view the turtles underwater. At first, everything seemed to be quite easy, safe and sedate. That is, until our tour guide started swimming out into the bay taking with him the baby in his floaty accompanied by his five guardians. Oh, and did I mention that we all had snorkel gear on our heads? Can you imagine the reaction of a 14-month-old baby being led into open water in a small swim raft surrounded by six 'aliens' swimming alongside him? Once he recognized his predicament, our usually happy, smiling grandson ... well ... freaked! A shrill, petrified cry began to herald from his inconsolable visage. Despite efforts to demonstrate the familiar earthliness of his parents and family-we rapidly removed our goggles and treaded water around him-not surprisingly, a swimming sprint back to shore and presentation of our unadulterated selves were required to (gradually) relieve his distress. What were we thinking?

But, that was not the crisis. I failed to mention that Tyler was traveling with an ear infection and was already on his second antibiotic - the cephalosporin cefdinir. The day after our near (turtle) fiasco his mother notified the accompanying gastroenterologist (me) that his 'poops' were coated with blood. He has always cried when straining to move his bowels and may have been a little 'constipated', but nothing was remarkable. He was healthy, happy, growing and had a fantastic and varied appetite. He was breast fed for 9 months and had been on formula and milk without issue for the previous 5 months. On vacation, he was happy through the day, had no problems eating or drinking and was his usual active self. He had been consuming Mexican milk for 3 days, but had no fever, vomiting or diarrhea: just the blood-coated stools that persisted over the next $48 \mathrm{~h}$.

I am not a pediatrician. My immediate differential diagnoses included an anal fissure, milk-protein colitis or a Clostridium difficile infection. I did see the stools and they were formed but surrounded by dark red blood. I could not identify an anal fissure. So, his father searched for clues on the internet and noted that the pasteurization process for milk is different in Mexico to the USA and therefore had the potential to expose the baby to proteins different from those found in milk from the USA. We therefore stopped all milk products.

I then e-mailed a pediatric gastroenterologist colleague who was concerned about the possibility of intussusception or a C. difficile infection and encouraged us to visit the emergency room at the local hospital, but I deferred. The baby was healthy in all other respects and we had already decided to stop all milk products. Over the next 2 days he continued to have blood 'marbled' with his formed stools, but he was not complaining (aside from indicating his complete distaste for the swim raft).

Repeated examination of his stools (vacation or not) made me less convinced that we were observing blood. So, back to searching on the internet. I reviewed the differential diagnosis of hematochezia and rectal bleeding in infants, but found no more clues. We considered that the Mexican black beans or red sauces he had been consuming might be responsible, but withholding them made no difference. Next, my daughter-in-law tried an internet search for "red stools in infants". What came up was informative and reassuring. It turns out that cefdinir interacts with iron in the diet or supplements and is 'well-known' to cause stools to appear a red or rust color. Unfortunately, the fact was not so widely known that either his pediatrician or my pediatric gastroenterologist colleague was aware of it. In addition, there was no warning on the bottle or accompanying literature to inform us of the possibility that cefdinir could cause 'harmless' red stools.

Now that we have returned from our vacation, I am pleased to report that Tyler is well, happy and back on his routine diet. As for us, we still love to travel despite the accompanying continuing medical education credits we could earn on each adventure.

doi:10.1038/nrgastro.2010.19

\author{
4 Repeated \\ examination \\ ... made \\ me less \\ convinced
}

that we were

observing

blood 77
Stephen B. Hanauer is the Editor-in-Chief of Nature Reviews Gastroenterology \& Hepatology.

Competing interests The author declares no competing interests. 